\title{
Reconceptualizing Our Work: The Connection Between ECE Students and Political Action
}

\author{
Michelle Jones, Brooke Richardson, and Alana Powell
}

\begin{abstract}
Michelle Jones is a registered early childhood educator and currently completing a master of arts in early childhood studies at Ryerson University. Her research focuses on childhood disability and the role of early childhood educators in inclusive education. Michelle is currently working as a researcher at the Childcare Resource and Research Unit investigating current policy approaches to remuneration and retention in the Canadian child care workforce. Michelle was co-chair of the Ryerson Student Childcare Advocacy Association as an undergraduate and graduate student. Email: michelle.jones@ryerson.ca
\end{abstract}

Brooke Richardson completed her SSHRC-funded PhD in policy studies at Ryerson University in 2017 and is currently working as a postdoctoral researcher in the sociology department at Brock University. Brooke has been actively teaching in Ryerson's School of Early Childhood Studies since 2012, working primarily to develop and teach early childhood education and care policy courses. Her research interests include the discursive representation of child care in social policy debates, the critical examination of the pan-Canadian child care movement, and care as political practice. Brooke is also president of the Association of Early Childhood Educators of Ontario.

Alana Powell is a registered early childhood educator who is completing a master of arts in early childhood studies at Ryerson University. Her research engages in critical exploration of care discourses in early childhood during Ontario's 2014 and 2018 provincial elections. She has been active in the Ontario child care advocacy movement for several years and was co-chair of the Ryerson Student Childcare Advocacy Association from 2016 to 2018. As a contract lecturer in an ECE diploma program, she strives to engage her students in developing a strong sense of professional identity and a critical perspective of the challenges facing the ECEC sector.

This paper takes the position that early childhood education students are an underutilized resource in strengthening the Canadian child care advocacy movement. The authors come to this topic as undergraduate and graduate students and a contract lecturermember in Ryerson's early childhood studies program. Over the past year and a half, we have worked with our peers and colleagues to establish and lead the Ryerson Student Childcare Advocacy Association. Drawing on student movement and devaluation of care literature, this paper describes and explores our opportunities and experiences reconceptualizing the value of early childhood education and care that motivated us to become student leaders in the child care advocacy movement. Ultimately, we hope to both illustrate that students can and do make a meaningful difference in advocacy efforts and inspire and support postsecondary early childhood education programs to build the political capacity of students in the broader child care movement.

Key words: student movements; Canadian child care movement; higher education; child care policy; early childhood educator
Canada has a long history of student activism (Bégin-Caouette \& Jones, 2014), yet early childhood education (ECE) students have been largely absent from the Canadian child care advocacy movement. Although ECE students are often aware of the forthcoming low wages and poor working conditions inherent in their chosen profession (Flanagan et al., 2013; Ferns et al., 2014), they are typically divorced from child care advocacy efforts. The authors of this paper take the position that ECE students are an overlooked political group with the potential to broaden and strengthen the Canadian child care advocacy movement.

We come to this topic an undergraduate and graduate student and a contract lecturer in Ryerson's early childhood studies (ECS) program. Over the past year and a half, we have had the opportunity to work with our peers and colleagues to establish and lead the grassroots Ryerson Student Childcare Advocacy Association (RSCAA). While student advocacy efforts have been taking place ad hoc within the 
Ryerson ECS program for decades, Brooke Richardson, the author who is a contract lecturer, felt there was a need to formalize these efforts in a sustainable way. While recognizing that simply establishing a group does not guarantee sustainability, we argue that formal group status within an institution at least provides a basic structure to keep advocacy efforts consistent and reliable over time. It also provides a space for students and faculty to mentor and support each other in ongoing efforts to be active in the movement.

We begin with an overview of recent federal and provincial child care policy developments and the RSCAA's involvement. After a brief review of the broader student movement literature, we then describe what has motivated and supported us to become leaders in the child care advocacy movement-primarily policy courses that provided the opportunity to critically examine the ongoing, systematic devaluation of care work. From here we discuss our experiences as leaders with the RSCAA and share some of our thoughts regarding what academic institutions might do to engage and encourage students to become actively involved in the child care advocacy movement. Given the ongoing struggles of child care advocacy organizations (particularly in Ontario where ECEs are required to be members of the non-advocacy-based College of Early Childhood Educators) we hope to begin a conversation with the academic and practicing, professional ECE communities regarding the inclusion of students as a central component of strengthening the child care advocacy movement. We hope to illustrate that ECE students can and do make a meaningful difference in Canadian child care advocacy efforts and that postsecondary ECE programs play a key role in inspiring students to take on the inherent challenges of this important work.

\section{Political context}

Canada has had a dynamic and sustained child care advocacy movement, primarily led by leaders in the women's movement, in the Post-World War II period (Prentice, 1989; Langford et al., 2013). Between February 2006 and October 2015, during the tenure of Conservative prime minister Stephen Harper, the movement faced significant challenges as national child care policy was reduced to a tokenistic cash transfer to parents (the Universal Child Care Benefit) and women's organizations were systematically defunded. In 2015, the sociopolitical context shifted when the self-proclaimed feminist Justin Trudeau won a majority Liberal government. However, in 2018, federal leadership on child care policy is still significantly lacking and the child care and allied women's movements are struggling to rebuild. Child care policy continues to be relegated primarily to provinces, which simply do not have the same scope or financial resources to address the ongoing issues of affordability, accessibility, and quality in the sector. Fortunately, several provinces (Ontario, Nova Scotia, Alberta, and Prince Edward Island), either have or are currently taking on child care as a policy priority, providing some hope and optimism for children, parents, and the child care workforce. In this article we focus specifically on Ontario because this is where the authors are located and have dedicated much of their advocacy efforts.

In the past year and a half, the Ontario Liberal government has made several valuable strides in child care policy. These include the appointment of an associate minister of early years and child care and a commitment to create 100,000 new licensed child care spaces in the next five years. The government has been transparent in reporting that these additional child care spaces will require at least 20,000 new early childhood educators (Ontario Ministry of Education, 2016a; Ontario Ministry of Education, 2016b). One of the government's first steps in pursuing this initiative was organizing and holding community town hall consultations where parents, community members, ECEs, students, and child care providers were invited to share their vision and ideas regarding future policy direction. The ministry also launched an online feedback survey where all Ontarians could easily contribute their ideas and suggestions.

Believing that the voice of student ECEs was necessary, RSCAA members attended several of these meetings and 
encouraged friends, peers, and colleagues to participate in the online survey. The RSCAA also drafted a consultation response in the form of an open letter, which was published online and shared widely through social media by members, allied peers, community organizations, and provincial advocacy groups. As the open letter garnered the attention of the public and media, a policy officer at the Ministry of Education reached out to the RSCAA to schedule a private consultation meeting where the students' voice was presented directly to policy leaders.

In the spring of 2017, this consultation process resulted in the Ministry of Education's Renewed Early Years and Child Care Policy Framework (The Renewed Framework). In addition to addressing the highly publicized and ongoing affordability and accessibility problems with the child care system, The Renewed Framework addresses the pressing workforce issues through a "recommendation to support a longer-term plan for growing the profession of early childhood educators and addressing the multiple complex issues facing the sector" (Ontario Ministry of Education, 2017, p. 36). While overall the framework was quite broad and did not include many specific details, we were excited that allied efforts with other child care organizations in the province had led to the inclusion of the workforce voice in the document. In fact, a direct quote from our open letter was highlighted in the text.

In our experience advocating in a time of new government initiatives, we believe student groups are able to uniquely support the larger child care movement by engaging in the difficult conversations necessary to alter the status quo. Unlike professional organizations and formal educational institutions that must remain bipartisan and are limited in the claims they can make (most receive operating funds from these governments), the unique grassroots structure of student groups allows us to apply partisan pressure on the provincial government. Rachel Langford and colleagues (2016) articulate the value of "conflictual cooperation" in relationships between advocacy groups and governments-a role that student groups are well positioned to embrace as a collective with a broader mandate.

\section{Student movements}

Historically, student activists have made significant contributions to broader social movements around the world (Altbach, 1989; Bégin-Caouette \& Jones, 2014; Broadhurst \& Martin, 2014; Linder \& Rodriguez, 2012; Quarter, 1972; Rhoads, 2016; Winston, 2013). Due to their substantial impact, researchers have studied student groups to identify features that distinguish them from other social activists and to document factors that relate to their success (Altbach, 1989; Bégin-Caouette \& Jones, 2014; Broadhurst \& Martin, 2014). Eric Swank (2012) suggests that the success of student movements may be related to the resources available through campus organizations and the flexibility of student schedules. Indeed, the RSCAA has benefitted from in-kind support (mainly access to meeting and event rooms at no charge) as well as the financial support from our school and student union. Grants awarded to the RSCAA allowed us to hold several successful events on campus, including a party congregating students for ECE Appreciation Day and a panel discussion on child care for International Women's Day. These opportunities were central to increasing the capacity of the RSCAA: We were able to extend our reach within the student population and allow for collaboration with more formal provincial advocacy organizations. These efforts also gave us a platform to get the attention of the provincial government, which stayed abreast of these events.

Research conducted on student activist leaders has often concluded that enrollment in the social sciences and humanities is a significant factor in their participation in social movements (Altbach, 1989). However, more recent research suggests that the completion of a social justice course is more likely responsible (Broadhurst \& Martin, 2014). These trends are advantageous for the child care movement, because most early childhood education programs are both within schools of community services and beginning to integrate social justice discourses. As students, taking policy courses that critically examine the devaluation of female-dominated workforces and 
developing broader sociopolitical critical thinking skills were vital experiences leading to our sustained student activism in the child care movement. At Ryerson, the course in the ECS program that challenges students to engage in macro-level policy issues recently shifted from an elective to a required course. Again, this shift provides encouragement and promise that more ECE students-at least within one institution-will have the opportunity to become involved in child care advocacy efforts.

Policy/advocacy-related courses now exist within some Canadian two-year ECE diploma programs, suggesting some recognition that contextualizing professional practice within the broader sociopolitical context is important to ECE students. However, as Langford (2008) notes, students often take these courses in their last year of study, decreasing their opportunity to apply this knowledge throughout their education and reducing the probability of engaging in student activism.

Even when students do form movements or become key allies of existing movements, there are some unique challenges. In relation to other social movements, student constituents have brief associations with their campus communities. This rapid turnover of "undergraduate generations" can have negative effects on the ability of student movements to create sustainable change (Altbach, 1989, p. 99). This is pertinent to the child care movement because many ECE students attend condensed two-year diploma programs. ECE students' fleeting association with their academic institution makes involvement in student activism that much more challenging. In recognition of this issue, the RSCAA has worked to engage members with the ongoing campaigns and initiatives of provincial organizations in hopes of encouraging continued political activism throughout their careers.

Given that student movements have historically made substantial contributions to broader social movements, it is critical that student ECEs join the child care advocacy movement in Canada. We believe heightened and sustained political participation of ECE students depends on academic institutions' ability to engage students on a sociopolitical level and nurture the critical examination of students' professional identity.

\section{"Professionalization" amid ongoing devaluation: Our motivation to become involved}

Child care in Canada was originally developed as a welfare service provided primarily through religious institutions to widowed or impoverished mothers who required access to the workforce (Friendly \& Prentice, 2009). Today, due to the necessity of dual incomes and the increase in single-headed families, child care is an essential social service widely used by Canadian families with young children.

In the last several decades, early childhood education and care has also become a priority for nations as a way to encourage economic and human capital development (Moss, 2006; Organisation for Economic Co-operation and Development, 2006; UNICEF, 2008). Due to the growing appreciation of early learning for children, parents, and the economy, there has been a focus on increasing the capacity of the child care workforce through requiring higher education levels and ongoing participation in professional development. It is becoming increasingly recognized that well-educated, autonomous, and adequately remunerated early childhood educators are the cornerstone of quality care (Halfon \& Langford, 2015; Moss, 2006; Urban, 2008, 2010).

This understanding has led to the development of policies that aim to professionalize the workforce (Urban, 2008). Indeed, the federal government's Multilateral Early Learning and Child Care Framework included provisions for quality that prescribed an increase in the number of "providers with early childhood education certification and/or participating in professional development and training" (Government of Canada, 2017). Yet despite the increasing professional expectations of ECEs, the working conditions, professional autonomy, and wages remain stubbornly poor (Halfon \& Langford, 2015; Urban 2008, 2010). These challenges are understood to result from the persistent 
devaluation of female-dominated early childhood learning and care work. Even the associate minister of early years and child care perpetuated this devaluation when she referred to registered early childhood educators as "caring smiles and helping hands" in the legislature on ECE appreciation day.

Several factors contribute to the devaluation of care work; however, most pertinent, in our experience, is the way that both neoliberal ideology and social conservative norms situate the work of early childhood educators. In prioritizing individual responsibility and market solutions, neoliberalism as a narrative and political ideology shifts early childhood education and care from a social good to a private responsibility (Moss, 2014). Equally problematic are social conservative values which assert the family as the primary and preferred site for the care and education of young children, ultimately positioning ECEs as substitutes for maternal care (Moss, 2006). We feel a poignant sense of injustice that our work, regardless of our level of education, continues to be seen as "innate" or "natural" for women (Bourgeault \& Khokher, 2006; England, 2005; England, Budig, \& Folbre, 2002; Halfon \& Langford, 2015; Macdonald \& Merrill, 2002; Teghtsoonian, 1997) and therefore justifies low wages and poor working conditions. It is this ongoing "professionalization gap" that ultimately motivated us, as ECE professionals, to become involved in the child care advocacy movement.

As we sat down to write about the experiences that led us to become student activists in the child care movement, we discovered that, collectively, our enrollment in policy courses had made the largest contributions. Learning about and labelling political ideologies and examining sociological processes through a critical lens, we became able to situate the devaluation of care work as external, rather than feeling that our own career choice was somehow less worthy of respect. We each engaged in our own process of reconceptualizing our work and committed ourselves to changing dominant narrative "truths" rather than taking them on as individual inadequacies. Below we each share some of our experiences.

Graduate student (Michelle). Even before I began my college diploma program, I understood the widespread undervaluing of early childhood education. Many of my friends and family questioned my decision to enrol in the program. As an ECE student, throughout my diploma and undergraduate degree, I would often sidestep questions about my studies or misstate my studies as child development. Answering "child development" over "early childhood education" allowed me to avoid unpleasant questions and negative assumptions. Due to the often implicit nature of devaluation of care, I cannot explain most reactions, but some of the more offensive interactions involved being told to marry a wealthy man or that I was too smart not to continue my education and become a primary teacher. I believe I received such negative responses to "early childhood education" because of the cultural bias toward female-dominated workforces (Osgood, 2010). Yet, child development received more positive reactions due to its masculine associations with biology and psychology and less emotional labour (Halfon \& Langford, 2015). (Ironically, as I finish up my graduate studies, I am quite critical of pedagogies of early childhood education that take a scientific child development lens, preferring a postmodern, reconceptualist, competency model of the child and their learning.)

It was not until my final semester in my undergraduate degree that I chose to take an elective policy course. I had already applied to the master of arts in early childhood studies program and believed that acquiring knowledge from a more respected base could assist in my future career. I remember learning about Stephen Harper's Conservative Party and the neoliberal and social conservative norms that worked to prevent accessible and affordable child care, deepen the devaluation of care work, and almost devastate child care advocacy organizations. This was my introduction to neoliberalism, which helped clarify for me the strongly held acceptance of child care as a market system rather than a public good and children as an individual and private responsibility. It also became clear to me that socially conservative assumptions on the role of women had established caring for children as innate. In that 
course, for the very first time, I finally believed my work was valuable and I began to consider myself an educated professional. I finally understood it was purely due to sociopolitical factors that I was underpaid and undervalued.

During the time I was taking the course, the Ontario government proposed changes to the regulations around age ranges, ratios, and group sizes. The government was not interested in improving child-caregiver interactions but instead was trying to make child care more accessible and affordable without a financial commitment. Through what I had learned about social policy and governments, I was able to recognize that the proposed child care regulations were in lieu of financial investments and were going to require early childhood educators to care for more children without greater remuneration. The proposed regulations would have provided more spaces but would have further marginalized early childhood educators. I joined the RSCAA to write an open letter to the provincial government opposing the regulation changes, and I have been an active member of the child care movement since. By the end of the course, I had begun to identify as a feminist and was resentful that our profession was being mistreated because we were a female-dominated workforce engaging in stereotypically "natural" work.

Undergraduate student (Alana). After completing a bachelor's degree in political science and deciding to pursue a diploma in ECE, I felt a surprising amount of push-back from my peers, some family members, and many colleagues who were openly confused by, and apprehensive of, my decision to study ECE. It was through comments like, "You have a degree, why don't you just apply to teacher's college?" or "You don't need to go to school for that" that I began to internalize the devaluation of care. It was explicit in their comments that being an ECE was not as prestigious as being a teacher, and that an ECE does not require specialized knowledges, values, and ethical practices, but is natural and innate. At the time, I did not have an understanding of the sociopolitical context to properly advocate for myself and my decision, and I would often just try to get out of the conversation as quickly as possible. Largely due to the dedication and mentorship of a faculty member, I was provided opportunities to explore the macro political level and understand its implications for children, families, and ECEs. As I engaged with the course materials and in conversations, not only did the injustice of these systems become more apparent, but I was shocked by the long history of efforts by dedicated advocates to change this reality and the marginal progress there has been. When I understood that low wages were not a result of the profession being less socially valuable, but less socially valued, I began to explore my role in creating real change. Upon my faculty's recommendation, I took a placement opportunity at a provincial advocacy association, where I developed my advocacy capacity and commitment to push back against the devaluation of care. These experiences solidified my commitment to the ECEC field. Without understanding the devaluation of care and the sociopolitical context, I likely would have finished my diploma, but instead of seeking a position as an RECE, I would have looked toward another career. It became almost a sense of responsibility that compelled my advocacy.

When I entered the workforce as an RECE, I was hopeful that my life would change. Despite an understanding of the low wages in the field, I believed that with a salaried full-time job I would finally be able to leave my part-time job as a bartender. Ultimately, I really wanted to start a family of my own. However, it quickly became apparent that my salary as an RECE would not be able to support a child-we could barely manage our current bills. I kept my part-time job as a bartender, working evenings and weekends with only the rare day off. I was essentially sacrificing my own goals so I could continue working as an RECE. My partner and I hoped that my working two jobs would be temporary, and that a higher-paying job, or new wage increases, would allow us to live a comfortable life without working a 60-hour work week. However, that never happened. After a year and a half of working two jobs around the clock, I realized this lifestyle was not sustainable. While shopping for a gift for my stepdaughter, I walked down the infant clothing aisle and found myself in tears. I recognized the toll my professional commitment to ECEC was having on my life. I knew my profession was valuable and socially important, both from my academic knowledge and experiences, but I could no longer live with the poverty-level wages I was earning. It was incredibly 
frustrating that I could earn a better living as a bartender than as an early childhood educator. While this experience compelled me to continue to advocate for child care, it also made me reevaluate my own career goals and pursue higher education to work on the macro level to effect policy change. I am currently beginning my journey as a master's student in the ECS program at Ryerson, where my ultimate goal is to be able to create real change in the field of ECEC.

Unfortunately I have realized that, at least in the foreseeable future, I will not be able to earn a decent, sustainable living working as an RECE directly caring for children. While I will stay in the field in some capacity, it will most likely be within a postsecondary education institution or at the policy level.

Contract lecturer (Brooke). As a first-year ECS student, I had never actually considered that politics was something that had anything to do with caring for and educating young children. When a professor of my first ECE class asked us to raise our hand if we thought understanding politics was important for ECEs, my hand, like those of my peers, remained on my desk. I had the idea in my head that children should be kept separate from the harsh world of politics. While this professor initially challenged my thinking when she insisted all hands should be up, it wasn't until a class two years later where I truly came to appreciate how politics and policy were/are the foundation of children's care experiences-particularly in the Canadian sociopolitical context that continues to deny children many of their ratified rights, including the right to quality child care services as specified in Article 18 of the UN Convention on the Rights of Children. I also began to see how neoliberal norms relegating care to the private sphere, combined with traditional social conservative norms situating care/education as "natural" for women, undermined the value of the work of early childhood educators. The sense of injustice, both for children and women, had a profound effect on my personal and professional goals and trajectory.

While I remain an ECE at heart, I first pursued an MA in early childhood studies, where my major research project examined the representation of child care policy in the 2006 federal election in Canada. My parents, who had been hesitant about my choice to enroll in an ECE program, were notably relieved when my master's work was successful and my focus was now policy. I was encouraged by both my family and my mentors to pursue doctoral research in policy studies, which I very recently completed. While I had been somewhat aware of people's wariness of my career path in early childhood studies prior to enrolling in the doctoral program, I was surprised at the overwhelmingly positive response I received when sharing with people that my latest degree was in policy. I felt that people were beginning to respect my knowledge and expertise and dedicated advocacy efforts as something valuable, where engaging in social justice related activities was more than a "passing phase" but a central component of who I am.

Today, I find myself struggling to find a place within academic institutions as my social justice orientated policy lens in the early years is not the focus of many ECE programs. Because I do not come from a "developmentalist" angle and am instead interested in advocating and building social infrastructure that empowers women and children simultaneously, my work does not translate well into prescriptive ECE teacher programs geared toward narrowly defined "developmentally appropriate practice." I am much more interested in engaging both children and adults in critiquing social structures and processes through an equity lens. This is something I unquestionably think that young children are capable of and provincial curriculum frameworks (e.g., Ontario's Renewed Framework discussed above, New Brunswick's Curriculum Framework for Early Learning and Child Care, and Alberta's Play, Participation, and Possibilities) are beginning to reflect.

Again however, the sector will not ever be able to actualize the vision expressed in these recent reconceptualist, social justice oriented curriculum documents if policies supporting their implementation do not change. The existing child care policy infrastructure is inadequate (e.g., in terms of adequate number of staff, high levels of education for staff, widespread access for children) and many educators across the country simply do not have 
the adequate education levels-let alone time or opportunity - to provide children with these rich early care and learning experiences. I believe child care professionals have a key role to play in changing this. As long as child care centres operate within a market-driven fee-for-service system where parent fees (revenues) and staff wages (expenditures) are fundamentally at odds with each other (wages are a critical factor in recruiting and retaining well-qualified staff), there is simply not the opportunity to provide children with consistent, responsive, and stimulating experiences. It is my position that some responsibility for inspiring and motivating ECE students to take on these systemic challenges falls to educational institutions. Without a concerted effort, it is unlikely that things will progressively change. In this way I find it incredibly difficult to focus on the micro level of "preparing" ECE students to work in the sector without addressing and deconstructing the fundamental macro-level problems with the sector.

\section{Possibilities moving forward}

As the current leaders of the RSCAA, we recognize that our time as students is limited. For this reason, students must have the opportunity to engage politically from the outset of their academic experiences. In hopes of creating a sustained child care advocacy movement at Ryerson, the RSCAA has been purposeful in reaching incoming students and encouraging leadership opportunities within the group. However, we believe a sustained student movement requires not only the interest of ECE students in creating change, but an academic culture that supports and encourages student advocacy from Day 1 of study.

In no way do we as individuals or leaders within the RSCAA claim to have the problem of engaging ECE students in the child care advocacy movement figured out. We struggle constantly to keep our efforts going, recruit members, and mobilize alongside already overburdened community organizations. We have been supported through ECE curricular requirements at various institutions that require students to attend child care advocacy events, engage in community mobilization, or participate in professional development opportunities. Indeed, the success of our events has unquestionably been influenced by students feeling pressure to meet curricular requirements. However, meeting these requirements does not necessarily become meaningful to students if they have not had the opportunity to situate their work/study in the broader sociopolitical environment. It has been our experience that it is the ongoing and sustained critical engagement with sociopolitical issues that contributed to the development of a professional identity that reinforced our commitment to advocacy. While workshops and community events offer opportunities to explore these issues, critically examining dominant narratives and societal structures is beyond the scope of "one-off" student engagements. Certainly, greater effort is needed.

It might also be helpful if faculty members (of all statuses) were encouraged to take leadership roles in student initiatives and outreach to community organizations. While this certainly occurs, it is typically individually motivated rather than something that is institutionally valued or supported. At the same time, we feel it is vital that educational institutions have well-developed processes allowing students to form groups and access resources. While we were successful in accessing some funding in our second year (mainly through applying and receiving an award), we faced significant delays in our requests for funds and other resources through other institutional means (mainly student union funds). Since we, and incoming students, cannot apply for the same award in subsequent years, the group's ability to have a strong presence on campus, bring people together, and mobilize has been undermined.

As we continued our education engaging with complex pedagogical and theoretical ideas and challenging the basic notions of caring for and educating young children, we regrettably all experienced a lack of respect for our professional knowledge from our own peers, colleagues, and even professors. In many cases we were encouraged to 
leave the child care sector for a "better" profession-as if we were too "good" to be early childhood educators. In one case, a mentor and educator we deeply respected at the time said: "Women like us should not let women like them (referring to ECEs) look after our children." She believed that women with graduate degrees should stay home and raise their own children, completely undermining the value of the very profession she was teaching. Comments like these are incredibly upsetting and disheartening for incumbent professionals and perpetuate narratives that continue to devalue care work. The authors have found that interactions with friends, family, professors, and community mentors who recognize the value of our professional knowledge have been invaluable in fostering our involvement in the advocacy movement. It has been essential to the construction of our professional identities to have professors respect the distinct professional knowledge held by academics and practicing ECEs and to not speak on behalf of the practicing profession when they themselves do not identify as ECEs.

The authors' experiences in policy courses that critically examined the current sociopolitical context and encouraged our engagement in advocacy informs our position that the inclusion of these courses is integral to building the capacity of ECE students to participate in the child care advocacy movement. We also suggest that material and learning from policy and/or advocacy classes be better integrated with other course materials. For example, while students learn about the importance of responsive interactions with infants, they are not given the opportunity to understand why infant rooms are typically overcrowded and understaffed in Canadian child care centres. It is our experience that understanding the broader context that creates these adverse circumstances allows early childhood educators to stop internalizing the challenges they face as professionals and identify real opportunities for change. Understanding policy goes beyond one course-it is a central component of every topic ECE students learn. To engage ECE students in the child care advocacy movement, social justice and policy must be a central component of learning in all areas.

\section{Conclusion}

After exploring our own experiences, we feel it is necessary for all ECE students to have the opportunity to explore and embed their work within the broader sociopolitical context of child care in Canada. Although many institutions offer advocacy courses, we argue that they do not inspire sustainable student activism because they do not explicitly explain the social constructions that devalue our work and create poor wages and working conditions. Once we understood that policies (or lack thereof) rooted in neoliberal and socially conservative values were the cause of devaluation of care, we could stop internalizing the injustice as a personal failure and see it as a systemic issue. This not only allowed us to identify actions that would influence change but also encouraged the construction of an enduring professional identity. The ability to stop internalizing the devaluation of care allowed us to recognize ourselves as professionals worthy of professional wages and working conditions. Our newfound professional identities unified us proudly as early childhood educators and sustained our participation within the child care advocacy movement. If all ECE students have the opportunity and constructive support to incorporate the political into their professional identity, the broader child care advocacy movement-which faces persistent challenges and an overall lack of resources-will be strengthened. Even if ECE students move into other fields of practice (typically primary teaching in the public school system) they will remain committed and passionate allies of the Canadian child care movement. 


\section{References}

Altbach, P. G. (1989). Perspectives on student political activism. Comparative Education, 25(1), 97-110.

Bégin-Caouette, O., \& Jones, G. A. (2014). Student organizations in Canada and Quebec's “Maple Spring." Studies in Higher Education, 39(3), 412-425. doi:10.1080/03075079.2014.896178

Bourgeault, I. L., \& Khokher, P. (2006). Making a better living from caregiving: Comparing strategies to improve wages for care providers. Canadian Review of Sociology, 43(4), 407-426. doi:10.1111/j.1755-618X.2006.tb01141.x

Broadhurst, C., \& Martin, G. L. (2014). Part of the "establishment"? Fostering positive campus climates for student activists. Journal of College and Character, 15(2), 75-86.

England, P. (2005). Emerging theories of care work. Annual Review of Sociology, 31(1), 381-399. doi:10.1146/annurev.soc.31.041304.122317

England, P., Budig, M., \& Folbre, N. (2002). Wages of virtue: The relative pay of care work. Social Problems, 49(4), 455-473. doi:10.1525/ sp.2002.49.4.455

Ferns, C., Friendly, M., University of Toronto Childcare Resource and Research Unit, University of Guelph Centre for Families, Work, and Well-Being, \& University of Manitoba Department of Sociology. (2014). The state of early childhood education and care in Canada 2012. Toronto, ON: Childcare Resource and Research Unit.

Flanagan, K., Beach, J., Varmuza, P., \& Child Care Human Resources Sector Council. (2013). You bet we still care: A survey of centre-based early childhood education and care in Canada. Highlights report. Ottawa, ON: Child Care Human Resources Sector Council.

Friendly, M., \& Prentice, S. (2009). About Canada: Childcare. Winnipeg, MB: Fernwood.

Government of Canada. (2017). Multilateral early learning and child care framework. Retrieved from https://www.canada.ca/en/ employment-social-development/programs/early-learning-child-care/reports/2017-multilateral-framework.html

Halfon, S. \& Langford, R. (2015). Developing and supporting a high quality child care workforce in Canada: What are the barriers to change? Our Schools, Our Selves, 24(4), 131-143.

Langford, R. (2008). Making a difference in the lives of young children: A discursive analysis of a pedagogical motivator in an Ontario early childhood education training program. Canadian Journal of Education, 31(1), 78-101.

Langford, R., Prentice, S., Albanese, P., Summers, B., Messina-Goertzen, B., \& Richardson, B. (2013). Professionalization as an advocacy strategy: A content analysis of Canadian child care social movement organizations' 2008 discursive resources. Early Years, 33(3), 302-317.

Langford, R., Prentice, S., Richardson, B., \& Albanese, P. (2016). Conflictual and cooperative childcare politics in Canada. International Journal of Child Care and Education Policy, 10(1), 1-20. doi:10.1186/s40723-016-0017-3

Linder, C., \& Rodriguez, K. L. (2012). Learning from the experiences of self-identified women of color activists. Journal of College Student Development, 53(3), 383-398.

Macdonald, C. L., \& Merrill, D. A. (2002). "It shouldn't have to be a trade": Recognition and redistribution in care work advocacy. Hypatia, 17(2), 67-83. doi:10.1353/hyp.2002.0038

Moss, P. (2006). Structures, understandings, and discourses: Possibilities for re-envisioning the early childhood worker. Contemporary Issues in Early Childhood, 7(1), 30-41. doi:10.2304/ciec.2006.7.1.30

Moss, P. (2014). Transformative change and real utopias in early childhood education: A story of democracy, experimentation, and potentiality. London, UK: Routledge.

Ontario Ministry of Education. (2016a). Change to Ontario cabinet increases focus on child care. Retrieved from https://news.ontario.ca/ opo/en/2016/08/change-to-ontario-cabinet-increases-focus-on-child-care.html

Ontario Ministry of Education. (2016b). Ontario creating 100,000 more licensed child care spaces. Retrieved from https://news.ontario. 
ca/edu/en/2016/09/ontario-creating-100000-more-licensed-child-care-spaces.html

Ontario Ministry of Education. (2017). Renewed early years and child care policy framework. Toronto, ON: Queen's Printer for Ontario. Retrieved from http://www.edu.gov.on.ca/childcare/eyccframework.html

Organisation for Economic Co-operation and Development. (2006). Starting strong II: Early childhood education and care. Paris, France: Author.

Osgood, J. (2010). Reconstructing professionalism in ECEC: The case for the "critically reflective emotional professional." Early Years, 30(2), 119-133. doi:10.1080/09575146.2010.490905

Prentice, S. (1989). Workers, mothers, reds: Toronto’s postwar daycare fight. Studies in Political Economy, 30, $115-141$.

Quarter, J. J. (1972). Student movements of the sixties: A social psychological analysis. Toronto: Ontario Institute for Studies in Education.

Rhoads, R. (2016). Student activism, diversity, and the struggle for a just society. Journal of Diversity in Higher Education, 9(3), $189-202$. doi:10.1037/dhe0000039

Swank, E. W. (2012). Predictors of political activism among social work students. Journal of Social Work Education, 48(2), $245-266$. doi:10.5175/JSWE.2012.200900111

Teghtsoonian, K. (1997). Who pays for caring for children? Public policy and the devaluation of women's work. In S. B. Boyd (Ed.), Challenging the public/private divide: Feminism, law, and public policy (pp. 113-143). Toronto, ON: University of Toronto Press.

UNICEF. (2008). The child care transition. Innocenti Report Card. Retrieved from https://www.unicef-irc.org/publications/pdf/rc8_eng. pdf

Urban, M. (2008). Dealing with uncertainty: Challenges and possibilities for the early childhood profession. European Early Childhood Education Research Journal, 16(2), 135-152.

Urban, M. (2010). Rethinking professionalism in early childhood: Untested feasibilities and critical ecologies. Contemporary Issues in Early Childhood, 11(1), 1-7. doi:10.2304/ciec.2010.11.1.1

Winston, F. (2013). Decisions to make a difference: The role of efficacy in moderate student activism. Social Movement Studies, 12(4), 414-428. doi:10.1080/14742837.2013.827569 